\title{
Archipel
}

ARCHIPEL Études interdisciplinaires sur le monde insulindien

102 | 2021

Varia

\section{Female Religious Authority among Tarbiyah Communities in Contemporary Indonesia}

Autorité religieuse féminine parmi les communautés Tarbiyah dans l'Indonésie contemporaine

Ai Fatimah Nur Fuad

\section{OpenEdition}

Journals

\section{Édition électronique}

URL : https://journals.openedition.org/archipel/2657

DOI : 10.4000/archipel.2657

ISSN : 2104-3655

Éditeur

Association Archipel

Édition imprimée

Date de publication : 31 December 2021

Pagination : 187-207

ISBN : 978-2-910513-87-0

ISSN : 0044-8613

\section{Référence électronique}

Ai Fatimah Nur Fuad, «Female Religious Authority among Tarbiyah Communities in Contemporary Indonesia », Archipel [En ligne], 102 | 2021, mis en ligne le 15 décembre 2021, consulté le 15 février 2023. URL : http://journals.openedition.org/archipel/2657 ; DOI : https://doi.org/10.4000/archipel. 2657 


\section{Female Religious Authority among Tarbiyah Communities in Contemporary Indonesia}

\section{Introduction $^{1}$}

Religious authority within Islamic contexts is usually understood as $u l a m a^{2}$ or religious leaders who have in-depth understanding and expertise in religious learning, especially in law and legal judgment. The traditional recognition of their authority lies, therefore, primarily on their knowledge of Islamic law. They have received religious training in interpreting Islamic law as laid out in the Qur'an (Islamic scripture) and Hadith (traditions of the Prophet) (Abou El-Fadl 2001a; 2001b; Hallaq 2001; Zaman 2002). Mandaville (2007:307) defined the holders of religious authority as "a class of scholars with privileged access to texts, methods, and traditions of knowledge that create their capacity to speak authoritatively on religious issues." They are trained scholars in key sources of Islamic knowledge such as Tafsir (exegesis), Fiqh (jurisprudence),

\footnotetext{
* University of Muhammadiyah Prof. Dr. Hamka. Jl. Limau II, Kebayoran Baru, Jakarta 12130, Indonesia. Email address: fatimah_nf@uhamka.ac.id.

1. I am grateful to Dr. Kevin Fogg (University of North Carolina at Chapel Hill) for providing critical, direct and detailed comments on this manuscript. I would also like to thank the AIFIS and RISTEK BRIN for a very insightful and impactful academic writing workshop in November 2020, and two anonymous reviewers whose comments helped me in revising and developing the content of the article.

2. This Arabic word (ulama: plural and alim: singular) is widely used by Muslims in the Middle East, Indonesia, and beyond to refer to religious scholars who have an important role in conducting $d a$ ' $w a$ and educating Muslims on Islamic discourses.
} 
Arabic/linguistics and other related Islamic sciences as the foundation of the discourse of Islam. These religious scholars, according to Sonn (2018), have served as "custodians of religious discourse," building on Zaman (2002:143)'s terminology, who refers to the ulama as "custodians of change."

In contemporary Indonesia, the understanding and practice of religious authority has shifted. This shift has transformed other aspects of religious discourses and practices. This transformation can be seen from the answer of the core query "who can speak authoritatively about Islam?" Indonesian Muslims used to look to ulama or religious figures who have a comprehensive Islamic knowledge. Currently in Indonesia, religious authority can be claimed by everyone: experts and laypeople. It has shifted and opened up primarily by transnational Islamist movements. This shift has indeed changed the nature of religious authority and undermined its traditional forms. Previous works have highlighted this changing nature of authority and the challenges faced by the more established religious authorities, such as the mass organizations Muhammadiyah and Nahdhatul Ulama (NU) (Azra, van Dijk, and Kaptein (eds.) 2010; Abdullah 2017; Arifianto 2019; Akmaliyah 2020; Wahid 2012). The shifting of religious authority is related to the emergence of new transnational Islamist movements that led to competition and contestation between old local Islamic organizations and new transnational movements. Various authors have also extended these works in regard to various Islamic movements or religious groups of individuals that actively construct their authority within their community (Burhani 2020; Sunarwoto 2016; Rijal 2020).

This article approaches the question of authority by focusing on women liqo activity in the Tarbiyah movement. Liqo (Arabic, meaning "gathering") is a religious gathering activity attended by a small group of trainees and their mentor. The liqo has been designed and developed for the purpose of training and teaching the religious knowledge and ideology of the Tarbiyah movement. The Tarbiyah movement (Gerakan Tarbiyah or Jama'ah Tarbiyah) was founded in 1983 by Hilmy Aminuddin, Salim Segaf al-Jufri, Abdullah Baharmus, and Encep Abdusyukur (sometimes spelled Acep Abdussyukur). It is influenced ideologically by a transnational da'wa movement in Egypt called the Muslim Brotherhood or Ikhwanul Muslimin. The liqo is used by the Tarbiyah movement as a mean to strengthen members' religious authority and to connect the da'wa of the Tarbiyah movement with the public goals of the movement's political vehicle, the Prosperous Justice Party (PKS). PKS is an Islamist party that emerged out of the Indonesian democratization process in 1998 and was established by the founders and cadres of the Tarbiyah movement to expand their $d a^{\prime} w a$ audience and to achieve their da' $w a$ goals through politics. It has consistently won around $7 \%$ of the national vote in recent elections and is regarded as the most ideological party in Indonesia (Permata 2013).

This paper seeks to answer the question of how the female members at the lower levels of the organizational hierarchy perceive and practice religious authority in terms of the relationship between the liqo, the Tarbiyah movement 
and the PKS. This paper unpacks the overall structure, ideology, and hierarchy of the liqo, especially as related to female members' religious authority within the Tarbiyah movement. The main objective of this paper is to examine the role of weekly liqo trainings of the Tarbiyah movement in shaping female religious authority within the Tarbiyah movement and broader society. I argue that although the highest level of religious authority within the Tarbiyah movement remains dominated by men, nevertheless female members have found an avenue to build and maintain their religious authority through the weekly liqo sessions.

This article builds on much research on religious authority in Indonesian Islam (Bruinessen 2013; Chaplin 2015; Machasin, 2010; Meuleman 2011) as well as research on Islam and gender relations in Indonesia and female Islamic authority in different contexts (Blackburn et al. 2008; Robinson 2012; SmithHefner 2017; 2013; Smith and Woodward 2016; Kalmbach, 2011; Kloos 2016; Kloos and Künkler 2016; Hefner 2016; Ismah 2016; van-Doorn Harder, 2011). However, none of these works relate to women religious authority in the Indonesian Tarbiyah movement. There are also works on various aspects of the Tarbiyah movement (Afrianty 2019; Arimbi 2017; Asyari and Abid 2016; Miichi, 2020; Rinaldo 2019; Woodward et al. 2013), but they have not specifically analyzed the religious authority among women members of the liqo. Thus, gender aspects within the liqo of the Tarbiyah movement and a focus particularly on women's religious authority still need further exploration. This article begins with an overview of the origin and nature of the liqo of the Tarbiyah movement, how it functioned as the main vehicle of their $d a$ 'wa ideology and religious authority. This is followed by a section highlighting the multiple layers of authority within the liqo: structure, ideology and hierarchy.

Using an ethnographic approach, the data were collected through interviews and observations. ${ }^{3}$ The initial data is based on my fieldwork conducted in Jakarta in 2012 and updated with additional data in 2016 and 2017. The fieldwork included in-depth interviews with 10 participants consisted of 7 female and 3 male participants from diverse positions of members of the Tarbiyah movement. The 7 females consisted of 1 leader (top level), 4 mentors (middle level) and 2 trainees (lower level). The 3 males were interviewed because of their roles as the leaders of the Tarbiyah movement. They are part of the top liqo hierarchy, the ideologues and the decision makers of the movement, and it is important to understand their ideological views and the implementation of those views vis-à-vis female religious authority within the movement. The female mentors and trainees were within an age range of 28-38 years old, and the female leader was 42 years old during the time of major fieldwork. They were all married with children and came from a similar milieu. The majority of them are neo-urban educated professionals who

3. Ethics approval for this research was from the University of Leeds, received in July 2012. All names of interviewees in this article are pseudonyms. 
migrated from small villages in Central or East Java. They moved to Jakarta to achieve their higher education or to work as young professionals. This profile of young, working mothers, educated and professional characterizes those who are most interested to actively join the weekly liqo training sessions and other activities of the Tarbiyah movement. They want to receive Islamic knowledge because all these female liqo mentors and trainees have no Islamic educational background before joining the liqo.

These women differed in terms of how long they had been in this liqo at the time I interviewed them. Their length in the liqo group ranged from 2 years to more than 10 years. Apart from interviews, the data were also collected through participant observation of their liqo trainings to understanding the structure, ideology and hierarchy of the liqo in relation to the construction of their religious authority. Fifteen observations of their liqo sessions took place in Jakarta and Tangerang, two big cities that border each other. During my observations, I saw, listened and wrote on how the liqo sessions were managed, designed, and conducted for each session of two to four hours, depending on the agreement among the mentor-trainees in each liqo group. I also observed how many lessons and what subjects were delivered by the mentor, how they were received and understood by the trainees, and to what extent these lessons shaped the religious authority among female trainees. Beside these 'formal' observations, many 'informal' observations outside the liqo sessions were also conducted daily through following other varieties of $d a$ 'wa-based activities such as during their charity or philanthropy events and their social and health services for their neighbours and their local community. Qualitative analysis of interviews of the female members and observations of their liqo sessions then provided data for investigating how religious authority is perceived, understood, and practiced by the female members of this Islamist movement.

\section{The Origin and Nature of Liqo}

Liqo is the key feature of the $d a$ ' $w a$ of the Tarbiyah movement to develop members' ideology and religious authority. One of the key founders and ideologues of the movement, Hilmy Aminuddin, has explained in the official text published by the movement, "The liqo is the main characteristic of a tandzim nukhbawi (cadre organisation)' [i.e., the Tarbiyah movement] (DPP PKS 2007a:7). It is the main religious training of all cadres of the Tarbiyah movement, both male and female. However, the liqo groups are designed exclusively for a single gender, with groups for men only and groups for women only. ${ }^{4}$ A liqo group is composed of a mentor and a limited number of

4. Men and women have separate liqo, and the Tarbiyah movement as a whole is non-transparent - even secretive - about total numbers of followers. However, based on years of fieldwork and also popular understanding of the Tarbiyah movement, the number of female followers (and thus, the number of female liqo) is understood to be 
6-10 permanent trainees. The liqo was called usrah (Arabic means "family") in the beginning of their emergence because the Tarbiyah movement applies the family system (nizam al-usrah), in which one person is chosen to be the leader of the group or head of the family. A male trainee of the liqo is called mutarabbi and female trainee mutarabbiyah, while the male mentor is called a murabbi and a female mentor murabbiyah. There are three levels of cadre groups in the liqo: Pemula and Muda (beginner), Madya (intermediate) and Dewasa (advanced) (DPP PKS 2005). These liqo levels are related to the progress of each trainee during and after joining the liqo and the length of their involvement as liqo members. They are connected to each other from the highest to the lowest level of cadres through their mentors.

From the Tarbiyah movement's emergence in 1983 until 1998, the liqo sessions were organised by a supreme leader (muraqib 'am), holding both religious and organisational authority. This leadership, however, changed after the establishment of the PKS political party in 1998. As a political party, the PKS follows the party's president under the guidance of the Shura Council (Majlis Shura). In the beginning of the Tarbiyah movement, the liqo was conducted in the corners of university mosques or trainees' houses. In the repressive period of the authoritarian regime of the early 1980s, the movement used covert $d a$ ' $w a$ approaches to prevent the movement from being shut down by the regime, which was hostile to political Islam. They hid the structure of the organisation including the trainers or mentors of the liqo and coordinators of the Tarbiyah movement. During this early period of the liqo, they held that 'the structural organisation [of the movement] is secret and the $d a$ ' $w a$ is open' (sirriyah al-tanzim wa 'alamiyah al-da'wa) (DPP-PKS 2003:27). A senior mentor of the Tarbiyah movement explained that this secret nature of the organisation led to a secret process for recruiting new cadres in the past. He said that the recruitment of new members for the weekly liqo was only undertaken among people close to existing members, and not openly among the wider society. ${ }^{5}$ As a result, at the very beginning of the 1980s this liqo had a very limited number of trainees and mentors.

According to leaders of the Tarbiyah movement, there were no wellstructured or well-organised materials and methods used in the liqo or $d a$ 'wa training during this early phase. The unstructured beginnings of the liqo of the Tarbiyah movement meant that the teaching materials at that point were taken from various sources that accommodated many different strands of Islamic thought. Neither were there any standard nor enforced methods for delivering their religious messages, which were largely left to the expertise of each individual mentor. These initial cadres obtained their religious knowledge and

significantly larger than male followers. Thus, the majority of the Tarbiyah movement is female.

5. Interview with Machmudi (40s, mentor, male) conducted in Jakarta, 18 August 2012. 
skills from their interactions with people and books that have links with the da'wa ideologies of Muslim Brotherhood in Egypt. The liqo weekly trainings were later gradually developed by key leaders of the Tarbiyah movement.

A more overt da' $w a$ approach started to be practised from the end of the 1980 s, when the Suharto regime began to become more accommodating of political Islam. Through the liqo, the Tarbiyah movement started to reach wider audiences and to convey its $d a$ 'wa messages by conducting a variety of more formal activities in bigger public spaces, for example, through giving lectures, sermons, running a variety of religious classes, and building publishing companies, educational and social centres. Through these programmes, the Tarbiyah movement attempted to attract new potential audiences to improve their religious knowledge and religiosity through the liqo. With the fall of the authoritarian government in 1998 and the subsequent rise of the post-New Order government, the Tarbiyah community took the opportunity to establish an Islamic political party; after some minor transformations in response to political upheaval in the democratic transition, this stabilized into the current PKS in 2003. The Tarbiyah leaders argued that the party would be utilised as their means for spreading their $d a$ 'wa messages.

\section{The Ideology of Liqo}

The liqo is the Tarbiyah movement's most powerful religious activity for disseminating and strengthening the da'wa ideology of its cadres. The early 1980s was the period in which the reforming of individual religiosity was emphasised as the Tarbiyah movement's da'wa ideology. As written in one of the movement's official books, the development of individual religiosity was the main goal of the Tarbiyah movement in this period.

After joining the liqo or other $d a$ ' $w a$ activities, trainees are expected [by the Tarbiyah movement] to be able to develop their individual religiosity, which includes: 1) having an understanding of the basics of Islam; 2) having good akhlaq (morals); 3) having no influence from any idolatry or polytheism (kemusyrikan); and 4) having no relationships with enemies of Islam [individuals or institutions] (DPP-PKS 2003:5).

Moreover, the leaders and senior activists of the Tarbiyah that I interviewed emphasised that their goal was to create individuals with certain Tarbiyahaligned characteristics known as al-muwashafat al-tarbawiyah (meaning "characteristics of Tarbiyah cadres") (DPP PKS 2003:5-9). Tarbiyah-based individual religiosity was created and developed through weekly liqo training. The training was intentionally directed by the Tarbiyah activists in a way that aims to develop syakhsiyah Islamiyah (Islamic personality), which covers beliefs (akidah), rituals (ibadah) and morals (akhlaq) of Muslims. In order to strengthen the formation of individual religiosity, the weekly training during the early phases of the liqo primarily discussed the issue of Islamic character. Subjects of tafsir (exegesis, interpretation, commentary, especially relating 
to the Qur'an), hadith (a record of the sayings and doings of the prophet Muhammad and his companions) and fiqh (jurisprudence) were taught to Tarbiyah activists with the aim not only of making them better Muslims in their daily lives but also to have more authority to share Islamic knowledge to their society and, in turn, to influence public religious discourses.

The Tarbiyah movement's emphasis on individual religiosity in their $d a$ 'wa movement was driven by their strong belief that to turn inwards towards the self is the best solution for Muslims' problems. This idea of individual religiosity endeavoured to establish a better religious understanding within Muslim individuals and the skills to apply this understanding to their daily lives (DPP PKS 2003: 1-3). One of the important lessons of individual piety preached by the Tarbiyah movement leaders is to encourage all of their members to be individuals who are closely 'connected with mosques' and leading religious activities in mosques in their daily lives. One of the leaders explained that the male Tarbiyah activists' regular attendance of public mosques for leading prayer and delivering sermons is part of the requirement relating to personal character-building that must be fulfilled by all Tarbiyah cadres:

[If they follow this guidance to come to the mosques frequently], they should be ready and active to offer any help in mosques, for instance for becoming a leader of prayer (imam); delivering religious sermons (khutbah or $\left.d a^{\prime} w a\right)$; or assisting other religious and social services at the mosques, such as giving alms (sadaqah). The Tarbiyah movement's doctrine that we really emphasised to the activists is that they work - just work with feelings of ikhlas (sincerity) and itqan (being wellstructured and professional), as has been taught by Islam. ${ }^{6}$

Ahmad believed that these activities represent the basis for building many other aspects of a pious Muslim man's character and activism. Male members in the movement have many choices to establish their religious authorities as an imam, ustadz, khotib, muballigh and $d a^{\prime} i$. They are strongly encouraged for leading religious activities in public places. ${ }^{7}$ As Noura explained:

The Tarbiyah (male) activists entered the mosques and religious institutions and most of them were known as ustadz [religious teacher] or muballigh [preachers]. Ustadz or muballigh have trained not only the younger activists in [the liqo] groups, but also gave Islamic lectures at various public places overtly, such as campuses, offices, and mosques. ${ }^{8}$

6. Interview with Ahmad (60, leader, male), conducted twice in Jakarta, 27 August 2012 and 17 October 2012.

7. During the early development of the liqo in the 1980s and the early and middle part of the 1990 s, this movement had numerous liqo figures well known among the liqo community. They are widely referred to using the title 'ustadz', which means teachers of religious knowledge or Islamic subjects. The title 'ustadz' was not because of a formal education or official appointment, but established through an informal process of recognition developed over years of interactions between the liqo and the Tarbiyah community.

8. Interview with Noura (50s, leader, female), conducted in Jakarta, 08 October 2012. 
Different spiritual roles beyond the liqo are options for men. However, many of these avenues are unavailable for women. Women's leadership roles in religious activities are restricted by the movement's theology to become a murabbiyah (mentor) inside the liqo. The liqo is the only opportunity for them to prove their religious authority. Although women in the Tarbiyah movement can have various opportunities and roles to prove their political leadership in parliament and other public appointments, still their spiritual leadership is manifested only in the liqo. From the interviews with both the senior activists and leaders of the Tarbiyah movement, it is shown that although this movement is run and dominated organizationally by women, still the religious authority emanates from men. Muslim women are still left out of positions of spiritual leadership in Islamic institutions or $d a$ 'wa movements in the Muslim world. This article confirms that access to positions of female religious leadership is difficult, though not impossible. It also known from previous literatures on Islamist movements, that gender equality and women's right are often neglected from this movement (Afrianty 2019; Arimbi 2017; el-Husseini 2016; Robinson 2019). Because the liqo is the only opportunity in the Tarbiyah movement for building and maintaining religious authority as women, it is important to study the dynamics of this one path toward (albeit limited) leadership.

The ideology of the liqo was heavily influenced by the ideology of the Egyptian Muslim Brotherhood. The overall $d a$ 'wa ideology of the Tarbiyah movement that attracted many members' interest in attending the liqo was driven by the same motives as the Muslim Brotherhood itself (Mitchell 1993). They worried about the attitudes of their government towards political Islam and the global political tendency that has led to the absence of Islam in the public sphere. They felt the need to improve their religiosity and to Islamise individuals, family, the society, and the state through their involvement in the liqo. In general, the liqo ideology approaches the question of authority by frequently linking it to the construction of a single or global religious community or movement. For a more specific example, the Tarbiyah movement often focused on trying to link the local movement to the global Islamist movement, and on the tendency to emphasize the global ummah (an Arabic word meaning community) over the local.

\section{The Structure and Hierarchy in Liqo}

Barker's study of new religious movements defines 'authority structure' as an 'organizational structure' that relates to a 'patterned structure of relationship which consist of a charismatic leader at the apex, transmitting information, ideology and command to trusted and limited lieutenants, who in turn pass the information down a hierarchy chain of command to grassroot level' (2005:70). Barker's analysis is also true in the case of the chain of 
hierarchy within the liqo of the Tarbiyah movement. The structure focuses on systems of community practice, mainly on how the community passes along organizational and ideological information and stays connected. The liqo is a multilevel organism, connecting, growing, and constantly building a network from its highest levels to its lowest. The highest levels are composed of those who have the longest experience in attending the liqo, and the lowest ones consist of those who have just joined. The mentors play an important role in connecting one level to another through their double position as both mentors of a lower liqo group and trainees in a higher group. Given that the majority of the liqo trainees belong to two liqo groups at the same time - as a mentor of one group and a trainee in another - the liqo network will continuously grow, because liqo trainees become mentors who share the same belief systems as new recruits. As a result, the transmission of liqo ideology from the top leaders of the Tarbiyah movement will be easily passed down to all liqo trainees at the grass-root level. In turn, the lowest level produces more liqo groups, because each trainee is encouraged by their mentors to invite new trainees as part of their $d a$ 'wa responsibility.

The trainee-mentor relationship is the most important tie in the liqo community since it connects liqo groups to one another and perpetuates not only the Tarbiyah movement, but also the PKS. The restrictions in the number of members of liqo groups aim for establishing a close connection between members of the liqo community - a 'familial relationship' that crosses beyond the kinship boundary. A female mentor explained: 'this condition creates a very close relationship between the mentors and their trainees, and among the trainees. ${ }^{9}$ This is why, in the past, the liqo was called usrah (family). A small family is established through the liqo groups, within which a sense of belonging, solidarity, and togetherness is built. My interviews with female trainees revealed that the weekly mentoring group is regarded by them as their 'second family.' This is one of the reasons why trainees stay in one liqo group for many years and are often not keen to move to the next liqo group level, which provides more advanced Islamic subjects. As one female mentor put it:

I have been mentoring one group of the liqo. Most of the trainees do not want to move to other groups, although I asked them to do so. They already feel comfortable with this group, so they rejected [placement] to other groups. I advised them to move to other liqo levels, considering that different female mentor will have different expertise, so that moving into other groups will be good for enriching their insight on Islam. ${ }^{10}$

9. Interview with Rahima (30s, mentor, female), conducted in Jakarta, 4 September 2012. 10. Interview with Athya (40s, mentor, female), conducted in Tangerang Banten, 22 October 2012. 
The mentors play the role of 'heads of families', being perceived as the teachers, educators, parents and role models for the trainees of each group. As my female interviewees (Rania, Rifa, Rahima, and Tania) argued and attested to, when liqo members get married, their mentors even play a significant role in the marriage process (Asyari and Abid 2016). According to Nancy Smith-Hefner (2019), this practice is a form of Islamisation of intimacies, romances, and marriages among young Muslims. She explains that there are shifted perceptions and practices of young Muslims' marriages, and this is one of the biggest transformations experienced by Indonesian Muslims. She points out that the traditions and practices among Javanese culture are regarded by Muslim youth as incompatible with the authentic Islamic norms. Thus, they want to be more active in practicing their 'pure and pristine' Islam as they believe. The Islamists generally hold the notion of active $d a$ ' $w a$ in responding to the dynamics of modern daily lives (Fuad 2019). During an interview, a young female mentor told me about her female mentor (murabbiyah) when she was an ordinary trainee:

Personally, I felt respect to my murabbiyah, due to her position as my teacher. Of course, I felt that the figure of murabbiyah is different to that of ordinary trainees. She is a role model for me. I preferred to consult and ask advice from my murabbiyah rather than from other liqo trainees or my [birth] family. ${ }^{11}$

Her statement also supports the idea that religious authority among the female liqo community is mainly invested at the local level amongst the trainees - that is, with the mentor rather than the organisation per se.

The liqo group I participated in clearly acted as one 'family', sharing their own life experiences and problems. Furthermore, they also asked and told each other about difficulties and problems concerning their families and daily activities. During my participation in the liqo, one of the trainees told the group about her child's sicknesses and overactive behaviour, and the other trainees then shared their personal experiences of dealing with such problems. ${ }^{12}$ In another case, one of the liqo trainees became severely ill and required hospitalisation. ${ }^{13}$ In the following liqo meeting, the trainees and the mentor all discussed how to help her. We then agreed to visit her in her house after she was back from the hospital and to give her a donation that we gathered between us. Such relationships facilitate the development of close and firm bonds among trainees, between the trainees and the mentor, and between the trainees, the mentor, and the movement. For these trainees, who are mostly migrants and live away from their close families, the liqo provides many benefits, especially in terms of therapy, support, and local community.

11. Interview with Rifa (30s, mentor, female), conducted in Jakarta, 5 September 2012. 12. Interview with Mona (30s, trainee, female), conducted in Tangerang Banten, 16 December 2012.

13. Interview with Saida (30s, trainee, female), conducted in Jakarta, 03 October 2012. 
Through their roles as teachers, parents, and role models, every mentor attempts to encourage their liqo trainees to be more committed to Islamic teachings, both during and outside the liqo sessions. They motivate the trainees to conduct prayers (both obligatory and recommended optional prayers). The mentors also give the trainees tasks, such as reciting more than ten verses of the Qur'an every day. Moreover, as heads of the 'families', the murabbiyah arrange other activities outside of liqo time. One murabbiyah commented:

We (murabbiyah) must think how to make the trainees of our group not to feel bored. We offer to arrange activities [for them] that can make them fresh. Therefore, the programme of gathering, eating together, and travelling were sometimes conducted. These are some of the cultural as well as personal approaches that are important to be done. ${ }^{14}$

When selecting a trainee to become a female mentor (murabbiyah), the mentor of a group will consider the capacity of the trainees in her group, and their familiarity with the liqo belief system. The murabbiyah thus emerge from the bottom of the liqo group - they are ordinary but experienced trainees, appointed by their own mentors. A commitment to behaving in an Islamic way and significant experience in the liqo are two of the main requirements to be selected as a murabbiyah. These requirements were explicitly mentioned by a few respondents, and most murabbiyah have been involved in the liqo longer than regular trainees (mutarabbiyah). There is an assumption among the liqo community that the longer they participate in the liqo, the more they will come to know about Islam. Consequently, those who have been in the liqo for a long period will be likely to be appointed as new murabbiyah.

\section{The Liqo and Religious Authority}

Max Weber in his Economy and Society (1968) explained three forms of legitimacy, namely, tradition, charisma, and legal-rational norms of authority. Traditional authority is founded on customary ideas, structures, and practices, while charismatic authority relies on personal magnetism, and legal-rational depends on institutionalized rules and practices (for more on these forms in connection with female religious authority in Islam, cf. Kalmbach, 2011). This concept, however, does not precisely or accurately represent the emerging new forms of authority within the Islamist movement. The liqo community is not traditional and makes no claim to traditional legitimacy. This community is also not charismatic because it cannot be legitimized by a single person. The forms of authority within this community are also not (fully) legalrational. Although the religious teachings within the liqo are the product of the hierarchical organization that spread and disseminate through a linear chain

14. Interview with Athya (40s, mentor, female), conducted in Tangerang Banten, 22 October 2012. 
of liqo, still the highest to the lowest levels of the hierarchy are not experts on religious judgment and knowledge.

The liqo population is mainly comprised of individuals with non-Islamic educational backgrounds (non-shar'i). Members of the Tarbiyah movement are mostly the products of secular institutions of higher education. They are well-educated neo-urban members of Indonesian society and thus most mentors are university graduates. However, only a few of these mentors have been educated in Islamic studies. ${ }^{15}$ Based on my reflections on what I saw during my fieldwork, a formal educational background in Islamic studies is not regarded as a key requirement for being appointed as a mentor. Instead, those who have more Islamic knowledge and have a strong sense of and connection to the ideology of the movement will be more likely to be seen as potential mentors.

This indicates that knowing the principles of Islam and $d a^{\prime} w a$ ideology of the Tarbiyah movement as taught in the liqo is one of the important requirements for becoming a murabbiyah, as one of the female mentors explained:

I believe that when someone is selected to be a murabbiyah, she must be competent and capable in that position. It is not possible that she will be selected as a murabbiyah if she does not know much about Islamic subjects. As far as I am aware, there are certain criteria required, such as those who are competent and capable in terms of their knowledge in Islamic subjects. It is possible for anyone to be a murabbiyah, regardless of their educational background. A murabbiyah is an obligatory responsibility in a group of liqo. I mean that everyone has the same chance and task to be a murabbiyah. However, they are required to meet certain criteria. ${ }^{16}$

Within the liqo, anyone with any educational background can build and prove their religious authority through their role as liqo mentor. The mentors also always encouraged their trainees to speak up about Islamic knowledge they got from the liqo weekly sessions and to share it to their closest community and to give fatawa (plural and fatwa singular, meaning legal opinions, religious guidance or instructions), even without sufficient Islamic qualifications. ${ }^{17}$ Fatawa in the contexts of female liqo members are limited to providing religious advice and explaining religious practices

15. Previous researchers (see Abdullah, 2020, Arifianto, 2019) highlighted that this Islamist movement is part of the new authority emerging in Indonesian Islam. The 'old' authority is challenged by this new authority. This liqo community is replacing religious authority of previous ulama and traditional Islamic authorities who trained in Islamic discourses through serious, long and in-depth training.

16. Interview with Rahima (30s, mentor, female), conducted in Jakarta, 4 September 2012.

17. Kalmbach (2011: 4) highlights that this phenomenon reflects 'the proliferation of religious knowledge and actors.' She reinforces that this is a new trend in Islamic thought and practice. She argues that there are changes in Islamic authority including in legitimacy, knowledge, and performance. 
by giving examples or drawing analogies from the sirah (stories about the Prophet Muhammad and his companions) or simple examples from Islamic jurisprudence relating to their everyday lives and situations.

As part of their $d a$ ' $w a$ missions and orientations, they were actively involved in responding to public religious issues within their society, especially their closest family, friends, neighbours and colleagues. According to van DoornHarder (2011: 414), these 'shari'ah-minded female activists eagerly want to transmit their religious knowledge to influence public debates. ${ }^{18}$ These female liqo activists will share their religious opinion based on their liqo teachings and ideologies through their informal activities.

Thus, religious authority and recognition from their 'inner circle' grow gradually through this personal relationships and informal activities. This 'inner circle' is regarded by Machasin (2010) as part of the closest individuals in their own community who are very loyal to them. Thus, they maintain their religious authority first and foremost among their local community. In most cases, the religious advice is provided orally and in a direct way of communication with liqo trainees and their close associates who are seeking advice. In contrast with the informal mechanisms of the liqo, fatawa in traditional Islamic discourses constitute formally issued recommendations on Islamic law based on Islamic legal sources, responding to Muslims' questions on various practices of Islamic law within their daily life. Thus, the primary qualification of granting fatawa has traditionally been an ability to interpret Islamic law, often premised on a formal Islamic education (Abou El-Fadl 2001a; 2001b; Hallaq 2001).

For these mentors, to be a murabbiyah gives them the opportunity to deepen and strengthen their knowledge of Islam. The higher the level in the liqo, the more advanced the subjects will be, and every time a topic is delivered in the weekly activity, the mentor must prepare it. As a result, they might learn additional information that was not imparted to them previously by their own mentors. Furthermore, by delivering the topic, they strengthen their understanding of the subject:

When my position was as a trainee, I enjoyed receiving as many lessons as possible. It is not the case when my role is a mentor like now. I have to obtain the Islamic subjects by reading as much as I can from many sources. This role supports me to get a deeper and wider understanding on Islam. ${ }^{19}$

18. Nelly van Doorn-Harder (2011) classified the Indonesian female activists into two namely pro-shari'ah agenda and anti-shari'ah agenda because they have different responses on a particular religious topic such as on the issue of polygamy.

19. Interview with Aliyah (40s, mentor, female), conducted in Jakarta, 23 September 2012. 
This 'cell' model of the liqo, and the mutarabbiyah-murabbiyah relationship it involves, are effective in spreading the $d a$ ' $w a$ ideology and authority among the female liqo community because they connect the groups to each other. Because the liqo is multi-layered, when members are appointed as mentors this does not mean that they cannot continue their learning within the liqo. Rather, they move to a liqo group with other mentors who are at the same level in terms of their participation and experience within the liqo and are then taught by a more senior mentor. The same pattern also runs among senior mentors at the next level, and this pattern continues until the highest liqo level is reached. Each liqo member learns about the liqo belief system through a more informed and experienced mentor, and the Tarbiyah network continues to grow. A common ideological orientation and its practice thus connect all liqo individuals and has led to a high level of unity in the liqo community. However, it has also produced segmentation among the internal community. The differences in personal views and religious interpretations, together with the liqo's development strategies sometimes cause divisions within the movement.

\section{Lower Level Female Authority in a Male Dominated Movement}

To understand the liqo at the lower level, we need to understand the broader Tarbiyah movement that is currently dominated by the PKS. Research conducted by Permata (2013) explains the internal dynamics of the Tarbiyah community and the PKS, which are caused by the different nature of the two institutions. He contends that the Tarbiyah movement is a secretive religious movement, managed informally under a supreme leader. The PKS, however, is a political party, managed under a party president who follows the formal political regulations and dynamics of the Indonesian system. Given that there are multiple levels within the liqo's hierarchy, there are also multiple levels of religious authority within the liqo community, and a chain of ideological authority for liqo trainees. The liqo hierarchy centered on the roles of top leaders or key figures of the movement in relation to their positions as the ideologues of the Tarbiyah movement/the PKS and interpreters of religious knowledge and practice within their $d a$ 'wa ideological framework.

Apart from the cadre's division of the Party Central Board (Dewan Pusat Partai, DPP), the Shari'ah Council (Dewan Shari'ah Partai, DSP) plays a significant role in giving religious advice to both liqo and PKS cadres. The DSP provides useful considerations for the political policies of the party through interpreting how to apply Islam to various issues. The DSP's role is not just to provide a religious reference point for the liqo community and the wider society, but also to maintain the religiosity of all liqo and PKS cadres, from the elite to the grassroots members. One of the PKS leaders emphasized this point as follows: 
The major role of DSP-PKS is to put shari'ah as the foundation of the party. The DSP has a responsibility to control and to maintain the obedience and compliance to shari'ah for both the party and its individuals. The individuals include elites and cadres from the highest to the lowest level of the party's membership. All leaders and activists [of the liqo] are required to have commitment to use shari'ah as the way of guiding their lives. For the party, the DSP needs to give guidance so that all policies or strategies do not deviate from the principles of shari'ah. ${ }^{20}$

The fact that the DSP requires the full obedience of all the different structures of the party, including the liqo cadres, suggests that the PKS/Tarbiyah movement is an 'authoritarian' religious movement (see Abou El Fadl 2001a). The DSP is the central body of the $d a$ 'wa party that is responsible for its shari' ah compliance and it frequently gives shari'ah rulings under various names, such as fatawa (legal opinion; religious guidance and instruction), bayanat (explanation), tadzkirah (reminder), qadla (decision), taushiyah (religious advice) and ittijah fiqh (jurisprudential guidance). These shari'ah or religious recommendations or religious rulings are issued to respond to the discourses or phenomena that occur within the Tarbiyah movement or the party.

In order to make appropriate legal opinions and decisions, 'the key figures of DSP should be experts on shari'ah who have graduated from a faculty of Shari'ah of any Islamic institution following postgraduate studies.' ${ }^{21}$ For example, Ahmad (60s) was among the traditionally trained religious authorities because he had received the religious training in the Faculty of Islamic Law during his Bachelor, Master and Doctoral degrees at the premier Islamic institution of the University of Al-Azhar in Cairo, Egypt. Other members of the DSP are also graduates in shari'ah from Middle Eastern universities. However, as a female national leader admitted, the Tarbiyah movement/ PKS has a very limited number of female members with a background in shari'ah (shar' $i$ activists). This is in line with the typical background of the liqo community, who are mostly 'lay' people rather than Islamically educated members or leaders. A senior shar' $i$ activist of the PKS who graduated from Al-Azhar University confirmed this:

The most dominant activists of the liqo are non-shar'i background. There are some members with a shar'i background from Medina or Al-Azhar University. However, it is very rare to find activists from the universities in Medina or Egypt. The most dominant and very active in mentoring new trainees are those who graduated from LIPIA (Islamic and Arabic College of Indonesia). ${ }^{22}$ When Medina or Egypt graduates return to Indonesia, it is very difficult for them to be

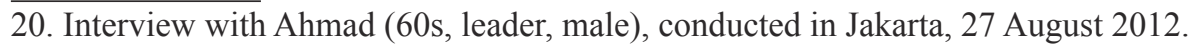
21. Interview with Noura (50s, leader, female), conducted in Jakarta, 18 October 2012. 22. LIPIA is a Saudi Arabia educational institution based in Jakarta, established in 1980. It is founded and coordinated by the Islamic University of Imam Muhammad bin Saud in Riyadh. 
're-educated' through the liqo/halaqah system and to join this da'wa community, as they may feel their superiority over others in terms of religious knowledge. ${ }^{23}$

The shari'ah rulings issued by the DSP thus provide guidance on how to live for all the liqo and PKS cadres. The DSP also fully supports and strengthens the Majlis Shura (Consultative Council) as the highest organisational structure in the PKS hierarchy. Although the Majlis Shura is above the DSP in the chain of command, and thus the latter has the responsibility of reporting its religious activities and decisions to the Majlis Shura, the DSP is regarded as the key 'think tank' of the Majlis Shura. ${ }^{24}$ The purpose of the DSP's involvement in the Majlis Shura is to maintain and fit together all the political and da'wa policies and ideologies with the shari'ah system. ${ }^{25}$ The Majlis Shura is the highest religious authority within the liqo community, including the female liqo community, as it is the highest religious and political entity in the PKS hierarchy. It has the power to control both the leadership and the ideology of the PKS, and is responsible for constructing ideological (theological) views. The Majlis Shura frequently issues rulings or advice related to the position of the party on the national stage, in terms of the party's theological and political views.

Despite the existence of such an extensive and authoritative hierarchy of experts at the top of the movement, the religious authority that is most frequently referred to by female liqo trainees is that of their liqo mentor. These murabbiyah also have their religious references in their liqo groups (the mentors of these mentors), and the same pattern of authority works its way up to the highest level of authority in the hierarchy. Given that a female mentor (murabbiyah) at one level is subordinate to mentors at the next level up, they should ask their murabbiyah if they do not understand issues concerning Islamic ritual ('Ibadah) or Islamic jurisprudence (Fiqh). Thus, each murabbiyah's interpretation of Islam is expected to have an ideological coherence with higher-level murabbiyah.

In order to make higher level murabbi's interpretations of Islam available, and thus enable this ideological coherence, the ideas of senior murabbi or key figures in the liqo-Tarbiyah such as Hilmy Aminuddin, Tiffatul Sembiring, and Anis Matta are disseminated and published on their official WhatsApp groups, websites, and in their books and pamphlets. ${ }^{26}$ The overall leadership of the

23. Interview with Arif(40s, leader, male), conducted in Tambun Bekasi, 18 October 2012. 24. Constitution and Bylaws of the PKS (Anggaran Dasar/Anggaran Rumah Tangga), MPP- PKS, 2008b.

25. Interview with Ahmad (60s, leader, male), conducted in Jakarta, 27 August 2012.

26. Books on the ideas of the top figures of the liqo/PKS community such as Anis Matta and others were published in 2007 by DPP PKS (see References). Although religious knowledge and advice are also disseminated through official website and WhatsApp groups and published though books and pamphlets, the liqo remains the primary way and most effective activity to pass down the leaders' ideas layer by layer 
liqo movement is, therefore, centralised by 'unity' on religious doctrines and practices. However, disagreements on particular issues regarding doctrines, practices, or the tactics to be used to achieve liqo goals can also be identified within the female liqo community at any level of the hierarchy. For instance, different liqo take various approaches to mobilizing cadres for political campaigns, even while following the general guidelines of the movement.

\section{Conclusion}

This article extends our understanding of female Islamic authority in contemporary Asia. It provides an investigation of female Islamic authority within the liqo of an Indonesian Islamist movement, called the Tarbiyah movement. The women members are encouraged by the Tarbiyah movement to develop their Islamic knowledge, religiosity and religious authority through joining the weekly liqo trainings. However, more public manifestations of authority such as leading prayer, preaching and providing religious counseling, are exclusive to male members of the Tarbiyah movement. Even though it remains difficult for women to enter and influence the internal religious spheres that are fully controlled by men, their weekly liqo sessions and other $d a ' w a$ activities are arranged and conducted by women. The only religious authority that these female members have comes from the structure of the Tarbiyah movement and the PKS (bureaucratic authority) through becoming a mentor (murabbiyah) in the liqo. Although the women in the liqo lack traditional educational credentials, as they are mostly graduates from non-Islamic educational backgrounds, they still actively maintain religious authority through their position as mentor (murabbiyah) of the liqo trainings. This practice suggests that the liqo of the Tarbiyah movement in Indonesia has shifted the religious authority as traditionally understood in Islamic history.

The liqo is the only powerful means for transferring the $d a$ ' $w a$ ideologies from the highest to the lowest level of liqo memberships. Remembering that the majority of the Tarbiyah movement is female, the primary way for members to get information from their top leaders is through the female mentors going down from level to level through the weekly liqo. Just as there are multiple levels within the liqo's hierarchy, there are also multiple levels of religious authority within the liqo community, and a chain of ideological authority for liqo trainees. However, I argue that although its leadership and authority exist on multiple levels, in which the Shura Council (Majlis Shura) of the PKS is the highest authority, the female mentors (murabbiyah) are regarded as the main reference point for the female liqo trainees (mutarabbiyah), especially at the liqo's lower levels. Religious decisions made by Shura Council (Majlis Shura) reach the members at a lower level and pass down layer by layer

to all liqo members until the lowest level of the movement. 
through the liqo. As a result, religious authority among the female members of the liqo of the Tarbiyah movement is reinforced because the female mentors are the ones bringing the decisions of the Shura Council (Majlis Shura) to the masses of the movement.

Although this research has shown how women in a conservative Islamic movement in Indonesia can accumulate religious authority, many questions remain about the broader position of women vis-à-vis Islamic authority in Indonesia. More research is needed to connect this finding to the ways women achieve other forms of authority (including, for example, prominent political positions) in conservative movements. We also need more research to compare and contrast female authority in this conservative movement with women in nonconservative movements in Indonesia, where the lack of the liqo structure means that this avenue is not available to female Muslims to build up authority. Finally, this case study in Indonesia should be compared with women in conservative movements in other parts of the world and their relationships to authority.

\section{References}

Abdullah A., 2020. "Religious Authority in Indonesian Islam: Mainstream Organizations under Threat." In: Saat. N. and Burhani A.N., eds. The New Santri: Challenges to Traditional Religious Authority in Indonesia. Singapore: ISEAS, 13-27.

Abou El-Fadl K., 2001a. And God knows the soldiers: The authoritative and authoritarian in Islamic discourses. Lanham, MD: University Press of America.

Abou El-Fadl K., 2001b. Speaking in God's name: Islamic law, authority and women. Oxford: Oneworld Publications.

Afrianty D., 2019. "Rising Public Piety and the status of women in Indonesia Two Decade after Reformasi.” TRaNS: Trans-Regional and National Studies of Southeast Asia, 8 (1), 65-80. https://doi.org/10.1017/trn.2019.14.

Akmaliyah W., 2020. "The demise of moderate Islam: new media, contestation, and reclaiming religious authorities." Indonesian Journal of Islam and Muslim Societies, 10 (1), 1-24. https://doi.org/10.18326/ijims.v10i1.1-24.

Arifianto A.R., 2019. "Rising Islamism and the Struggle for Islamic Authority in PostReformasi Indonesia." TRaNS: Trans-Regional and National Studies of Southeast Asia, 8 (1), 37-50. https://doi.org/10.1017/trn.2019.10.

Arimbi D.A., 2017. "Politicizing Piety: Women's Rights and Roles in the Tarbiyah Movement in Indonesia." Religious Studies and Theology, 36 (2), 228-244.

Asyari and Abid., 2016. "Expanding The Indonesian Tarbiyah Movement through Ta'aruf and Marriage." Al-Jāmi'ah: Journal of Islamic Studies, 54 (2), 337-368.

Azra, A.; Van Dijk, K.; Kaptein, N.J.G. eds., 2010. Varieties of Religious Authority. Singapore and Leiden: ISEAS and IIAS.

Barker E., 2005. "Crossing the boundary: New challenges to religious authority and control as a consequence of access to the Internet." In: M. Hojsgaard \& M. Warburg, Eds. Religion and Cyberspace. London: Routledge, 67-85.

Bruinessen M. V., 2013. Contemporary Development in Indonesian Islam: Explaining the 'Conservative Turn.' Singapore: ISEAS. 
Burhani A.N., 2020. "Muslim Televangelists in the Making: Conversion Narratives and the Construction of Religious Authority." The Muslim World, 110 (2), 154-175. https://doi. org/10.1111/muwo.12327.

Campbell H., 2007. "Who's Got the Power? Religious Authority and the Internet." Journal of Computer-Mediated Communication, 12, 1043-1062. https://doi.org/10.1111/j.10836101.2007.00362.x.

Chaplin C., 2015. "Islamic social movement in post-Suharto Indonesia: Life politics, religious authority and the Salafiyya." In: Petrů, T. (ed.), Graffiti, Converts and Vigilantes: Islam Outside the Mainstream in Maritime Southeast Asia. Vienna: Caesar Press, 31-52.

Damanik A.S., 2002. Fenomena Partai Keadilan: Transformasi 20 tahun Gerakan Tarbiyah di Indonesia. Jakarta: Teraju.

DPP PKS., 2003. Manajemen Tarbiyah Anggota Pemula. Bandung: DPP PKS dan PT Syamil Cipta Media.

DPP PKS., 2005. Manhaj Tarbiyah PK Sejahtera. Jakarta: Media Insani Press.

DPP PKS., 2007a. Dari Qiyadah untuk Para Kader; KH Hilmy Aminuddin. Jakarta: DPP PKS and Arah Press.

DPP PKS., 2007b. Seri Pemikiran Anis Matta; Integrasi Politik dan Dakwah. Jakarta: DPP PKS and Arah Press.

DPP PKS., 2007c. Bunga Rampai Pemikiran Tiffatul Sembiring. Jakarta: DPP PKS and Arah Press.

El-Husseini R., 2016. "Is Gender the Barrier to Democracy? Women, Islamism, and the 'Arab Spring." Contemporary Islam, 10, 53-66.

Fuad AFN., 2019. "Modernity and the Islamists Notion of Active Da'wa." Afkaruna: Indonesian Interdisciplinary Journal of Islamic Studies, 15 (2), 187-201. http://dx.doi.org/10.18196/ AIIJIS.2019.0102.187-202.

Fuad AFN., 2020. "Da'wa and Politics; Lived Experiences of the Female Islamists in Indonesia." Contemporary Islam, 14 (1), 19-47. https://doi.org/10.1007/s11562-01900442-x.

Hallaq W.B., 2001. Authority, continuity, and change in Islamic law. Cambridge: Cambridge University Press.

Hefner C.-M., 2019. "Models of Achievement: Muslim Girls and Religious Authority in a Modernist Islamic Boarding School in Indonesia.” Asian Studies Review, 40 (4), 564-582.

Hilmy M., 2010. Islamism and Democracy; Piety and Pragmatism. Singapore: ISEAS.

Ismah N., 2016. "Destabilising Male Domination: Building Community-Based Authority among Indonesian Female Ulama." Asian Studies Review, 40 (4), 491-509.

Kalmbach H., 2011. "Introduction: Islamic Authority and the Study of Female Religious Leaders.” In: Bano. M., ed., Women, Leadership, and Mosques: Changes in Contemporary Islamic Authority. Leiden: Brill, 1-27. https://doi.org/10.1163/9789004209367_002.

Kloos D., 2016. "The salience of gender: Female Islamic authority in Aceh, Indonesia." Asian Studies Review, 40 (4), 527-544.

Kloos D. and Künkler M., 2016). "Studying Female Islamic Authority: From Top Down to Bottom-up Modes of Certification." Asian Studies Review, 40 (4), 479-490.

Luthfi A., 2002. "Gerakan Dakwah di Indonesia." In: Ash-Shidiqy ed., Bang Imad: Pemikiran dan Gerakan Dakwahnya, Solo: Gema Insani Press, 158-163. 
Machasin, 2010. "Struggle for Authority: Between Formal Religious Institution and Informallocal Leaders." In: Azra, A.; Van Dijk, K.; Kaptein, N.J.G. (eds.), Varieties of Religious Authority. Singapore and Leiden: ISEAS and IIAS, 115-125.

Mandaville P.G., 2007. Global Political Islam. London: Routledge.

Meuleman J., 2011. "Da'wa, Competition for Authority, and Development." Bijdragen tot de Taal-, Land- en Volkenkunde, 167 (2/3), 236-269.

Miichi K., 2020. Post-Islamism Revisited: The Response of Indonesia's Prosperous Justice Party (PKS) to Gender-Related Issues. The Muslim World, 110, 589-604.

Mitchell R., 1993. The Society of the Muslim Brothers. Oxford: Oxford University Press.

MPP PKS, 2008. Ringkasan Platform Kebijakan Pembangunan PKS dan Isu-isu Nasional berbasis Platform. Jakarta: MPP PKS.

Van Doorn-Harder P., 2011. "Translating Text into Context: Muslim Women Activists in Indonesia." In: Bano. M (ed.), Women, Leadership, and Mosques: Changes in Contemporary Islamic Authority. Leiden: Brill, 413-436.

Permata A.N. 2013. "A study on the internal dynamics of the Justice and Welfare Party (PKS) and Jama'ah Tarbiyah." In Regime change, democracy, and Islam: the case of Indonesia. Leiden: Universiteit Leiden, 241-294.

Rijal. S., 2020. "Performing Arab Saints and Marketing the Prophet: Habaib and Islamic Markets in Contemporary Indonesia." Archipel, 99, 189-213. https://doi.org/10.4000/archipel.1719.

Rinaldo R., 2019. "Obedience and Authority among Muslim Couples: Negotiating gendered Religious Scripts in Contemporary Indonesia.” Sociology of religion, 80 (3), 323-349. https://doi.org/10.1093/socrel/sry045.

Smith-Hefner N., 2013. "Indonesian Women and Islam.” In: Delong-Bas N.J. (ed.), The Oxford Encyclopaedia of Islam and Women. New York: Oxford University Press.

Smith-Hefner N., 2017. “Gender and Religious Change in Muslim Southeast Asia.” In: Sofjan. D., ed., Religion, Public Policy and Social Transformation in Southeast Asian Religion, Identity and Gender. Vol. 2. CRCS-ICRS Publication. Geneva: Globethics.net, 35-55.

Smith-Hefner N., 2019. Islamizing Intimacies: Youth Sexuality and Gender in Contemporary Indonesia. Hawai: Hawai University Press.

Smith B.J. and Woodward. M., eds, 2014. Gender and Women in Indonesian Islam: Leaders, Feminists, Sufis and Pesantren Selves. New York: Routledge.

Sonn T., 2018. "Continuity and Change in Religious Authority among Sunni Arabs." Sociology of Islam, 6, 141-164.

Sunarwoto, 2016. "Salafi Da'wa Radio: A Contest for Religious Authority." Archipel, 91, 203230. https://doi.org/10.4000/archipel.314.

Taji-Farouki S., 1996. A fundamental quest: Hizb al-Tahrir and the search for the Islamic caliphate. London: Grey Seal.

Wahid D., 2012. "Challenging Religious Authority; the Emergence of Salafi in Indonesia." Journal of Indonesian Islam, 6 (2), 245-264. http://dx.doi.org/10.15642/JIIS.2012.6.2.245-264.

Weber M., 1968. Economy and Society. California: University of California Press.

Wiktorowicz Q., 2001. The Management of Islamic Activism; Salafis, the Muslim Brotherhood, and State Power in Jordan. New York: State University of New York.

Wiktorowicz Q., 2005. Radical Islam Rising; Muslim Extremism in the West. Lanham, Md: Rowman and Littlefield publishers.

Wiktorowicz Q., 2006. Anatomy of the Salafi Movement. Studies of Conflict and Terrorism, 29 (3), 207-239. 
Wiktorowicz Q., ed., 2004. Islamic Activism; A Social Movement Theory Approach. Indiana: Indiana University Press.

Woodward M. et al., 2013. "Getting Culture: a new Path for Indonesia's Islamist Justice and Prosperity Party?” Contemporary Islam, (7), 173-189.

Zaman M.Q., 2002. The Ulama in Contemporary Islam: Custodian of Change. Princeton, NJ: Princeton University Press.

Zaman, M.Q., 2012. Modern Islamic Thought in a Radical Age: Religious Authority and Internal Criticism. Cambridge: Cambridge University Press. 
